\title{
PEMANFAATAN WAKTU LUANG MAHASISWA PROGRAM STUDI ILMU KEOLAHRAGAAN FAKULTAS ILMU KEOLAHRAGAAN UNIVERSITAS NEGERI YOGYAKARTA
}

\author{
Oleh: Dapan dan Fajar Setyawan \\ Dosen Jurusan Pendidikan Kesehatan dan Rekreasi FIK UNY
}

\begin{abstract}
Abstrak
Penelitian ini dilaksanakan untuk mengetahui pemanfaatan waktu luang mahasiswa Program Studi Ilmu Keolahragaan FIK UNY.

Penelitian ini merupakan penelitian observasional dengan menggunakan angket. Populasi yang digunakan dalam penelitian ini adalah mahasiswa Program Studi Ilmu Keolahragaan FIK UNY angkatan 2004, 2005, 2006, dan 2007, yang masih terdaftar sebagai mahasiswa dan belum mengajukan Tugas Akhir Skripsi. Jumlah populasi sebanyak 103 orang mahasiswa. Penentuan jumlah sampel menggunakan Nomogram Harry King, dengan tingkat kesalahan 0,08, maka diperoleh jumlah sampel sebanyak 60 orang mahasiswa, yang diambil secara random. Pengujian Validitas menggunakan product moment dan pengujian Reliabilitas dalam penelitian ini menggunakan rumus alpha cronbach. Untuk menganalis data yang terkumpul, digunakan analisis statistik deskriptif dengan persentase.

Hasil penelitian menunjukkan bahwa dari 60 mahasiswa, 1 orang $(1,7 \%)$ dalam kategori sangat baik, 6 orang $(10 \%)$ dalam kategori baik, 26 orang (43,3 \%), dalam kategori cukup, 23 orang (38,3\%), dalam kategori kurang, dan 4 orang $(6,7 \%)$ dalam kategori sangat kurang. Dari perhitungan rerata dapat disimpulkan bahwa pemanfaatan waktu luang mahasiswa dalam kategori cukup.
\end{abstract}

Kata Kunci: waktu luang, mahasiswa

Penggunaan waktu bagi setiap orang berbeda-beda, hal ini tergantung pada kebiasaan seseorang, pekerjaan seseorang, sasaran hidup seseorang, status ekonomi, lingkungan, dan banyak faktor penyebab lainnya. Orang yang sudah berkeluarga cenderung lebih banyak mempergunakan waktu untuk bekerja, sedangkan anak-anak dan remaja cenderung lebih banyak mempergunakan waktu untuk bermain. Demikian juga dengan mahasiswa, dalam www. pintunet. com dijelaskan bahwa penggunaan waktu luang mahasiswa untuk melakukan berbagai macam kegiatan sesuai dengan minat dan keinginan masingmasing mahasiswa, baik di lingkungan kampus, rumah, maupun lingkungan lainnya, 
seperti; mengikuti kegiatan kerohanian, mengikuti pendidikan keluarga, mengikuti kegiatan kemasyarakatan, kegiatan rekreasi, dan olahraga. Sejauh pengamatan peneliti, para mahasiswa Ikora belum banyak yang mengikuti kegiatan Unit Kegiatan Mahasiswa (UKM) di UNY terutama UKM bidang olahraga.

Jensen (1977: 2) menyatakan bahwa waktu dalam sehari terbagi menjadi tiga, yaitu: waktu bekerja (economic requirements), waktu memelihara diri (biological requirement), dan waktu luang (leisure time). Pengertian waktu luang sering pula disebut dengan istilah leisure. Wwn.popsy.wordpress.com melihat arti istilah waktu luang dari tiga dimensi: (1) Dilihat dari dimensi waktu, waktu luang dilihat sebagai waktu yang tidak digunakan untuk bekerja, mencari nafkah, melaksanakan kewajiban, dan mempertahankan hidup. (2) Dari segi cara pengisian, waktu luang adalah waktu yang dapat diisi dengan kegiatan pilihan sendiri atau waktu yang digunakan dan dimanfaatkan sesuka hati. (3) Dari sisi fungsi, waktu luang adalah waktu yang dimanfaatkan sebagai sarana mengembangkan potensi, meningkatkan mutu pribadi, sebagai kegiatan terapi bagi yang mengalami gangguan emosi, sebagai selingan dan hiburan, sarana rekreasi, atau sebagai kegiatan menghindari sesuatu.

Menurut Rubadi dan Syukur (1997: 17) waktu luang dapat dibagi menjadi beberapa macam, yaitu: waktu pada saat/hari efektif belajar (pada waktu istirahat diantara jamjam pelajaran), waktu di luar jam pelajaran (pada waktu sore, hari minggu, dan hari besar), dan waktu libur sekolah (libur semester, dan libur panjang). Menurut Muhammad dan Yudha (2000: 2) "waktu luang adalah rekreasi." Walaupun demikian, ada beberapa karakteristik tertentu agar suatu kegiatan dapat dikatakan rekreasi. Lebih lanjut Muhammad dan Yudha (2000: 3) menjelaskan pengertian rekreasi melalui dua sudut, yaitu pengertian secara tradisional dan pengertian secara kontemporer. Dari pandangan tradisional rekreasi adalah aktivitas waktu luang baik yang dilakukan secara individu atau kelompok tidak terikat oleh siapapun guna mencapai kepuasan. Dalam pandangan kontemporer rekreasi merupakan aktivitas pengisi waktu luang yang dilakukan secara individu atau kelompok tanpa paksaan dengan melibatkan unsur fisik, psikis, emosional, dan sosial yang mengandung sifat sebagai pemulihan kembali keadaan yang ditimbulkan akibat aktivitas rutin.

Hartoto (1983: 40) mengelompokkan kegiatan pemanfaatan waktu luang berdasarkan tempat kegiatan menjadi kegiatan indoor, dan outdoor. Kegiatan indoor adalah kegiatan yang dilakukan di dalam ruangan, seperti: olahraga dalam ruangan, pertunjukan seni, hobi, musik, dan lain-lain, sedangkan kegiatan outdoor adalah kegiatan yang dilakukan di luar ruangan, seperti: olahraga lapangan, hobi, musik, kesenian, dan lain-lain. Hampir semua kegiatan dapat dimasukkan ke dalam kedua kategori kegiatan ini, yang membedakan hanyalah tempat melaksanakan kegiatan tersebut.

Menurut Tim Abdi Guru (2004: 3) bentuk-bentuk kesenian ada empat, yaitu: (1) Seni musik, yaitu kesenian yang diwujudkan melalui media suara baik suara manusia maupun alat musik. Contohnya: bernyanyi, memainkan alat musik/main band, menciptakan musik, mendengar musik, menonton pertunjukan musik, dan lain-lain. (2) Seni drama 
(termasuk seni pertunjukan), yaitu kesenian yang diwujudkan melalui media gerak, suara, rupa, dan bahkan tari, seperti: teater, wayang, ketoprak, film, dan lain-lain. (3) Seni rupa, yaitu kesenian yang diwujudkan melalui media titik, garis, bidang, bentuk, warna, dan tekstur, seperti: fotografi, melukis, memahat, kaligrafi, seni kriya, dan lain-lain. (4) Seni tari, yaitu kesenian yang diwujudkan melalui media gerak tubuh manusia, seperti: tari tradisional, dansa, bąlet, senam, breakedance, dan lain-lain.

Olahraga merupakan salah satu bentuk aktivitas rekreasi. Menurut Haag (1994: 85) rekreasi dengan olahraga di waktu luang adalah bentuk aktivitas jasmani yang dilakukan pada waktu luang, seperti: olahraga setelah bekerja, pada saat weekend, dalam masa liburan, dan selama massa menganggur/cuti. Pengertian olahraga menurut UNESCO, dalam Rusli dan Sumardiyanto (2000: 6) adalah "setiap aktivitas fisik berupa permainan yang berisikan perjuangan melawan unsur-unsur alam, orang lain, ataupun diri sendiri." Lain dengan definisi menurut Dewan Eropah, dalam Rusli (2001: 39) yang menyebutkan "olahraga sebagai aktivitas spontan, bebas, dan dilaksanakan selama waktu luang."

Menurut Hartoto (1990: 5) kegiatan olahraga rekreasi merupakan kegiatan olahraga yang telah mengalami perubahan yang disesuaikan dengan tujuan, kebutuhan, karakter, nilai-nilai, dan prinsip rekreasi. Dijelaskan pula bahwa salah satu bentuk olahraga rekreasi adalah permainan. "Permainan merupakan kegiatan yang dilakukan secara spontan karena adanya dorongan keinginan dari dalam diri pelakunya untuk tujuan-tujuan tertentu." Lebih lanjut dikatakan bahwa ada beberapa komponen yang terkandung dalam permainan, yaitu: spontan, tidak beresiko tinggi, daya cipta sesuai dengan fantasi, merupakan imitasi dari tingkah laku orang dewasa, dan sifatnya kontemporer. Beberapa permainan tradisional antara lain: gobag sodor, egrang, jamuran, boy-boynan, dan lain-lain. Kegiatan petualangan di alam terbuka dan aktivitas outdoor yang sekarang disebut outbond juga merupakan salah satu bentuk rekreasi. Kegiatan tersebut cenderung bersifat non-kompetitif dan lebih mengutamakan pada pengalaman-pengalaman yang menyenangkan, menggembirakan, menantang, hubungan sosial, memperoleh pengakuan, dan rasa percaya diri dalam usahanya untuk mencapai keberhasilan.

Menurut Butler (1976: 375) aktivitas sosial adalah kegiatan yang bertujuan mengembangkan hubungan yang baik diantara individu-individu. Contohnya: berkencan, mengikuti pesta, pariwisata, ke tempat hiburan, mengikuti pertemuan-pertemuan, dan permainan sederhana, seperti; monopoli, puzzle, catur, karambol, dan bermain kartu, sedangkan menurut Rusell (1982: 156) rekreasi sosial adalah kegiatan yang mengarahkan seseorang untuk berhubungan sosial dan menjaga hubungan dengan orang lain. Kegiatan rekreasi sosial merupakan kegiatan yang menyenangkan, kegiatan yang ada unsur kerjasamanya dan menghargai orang lain, serta kegiatan yang bersifat sosial.

Mahasiswa prodi Ikora adalah mahasiswa Fakultas Ilmu Keolahragaan yang memiliki karakteristik yang hampir sama dengan mahasiswa lainnya. Usia mahasiswa prodi Ikora antara 18 tahun sampai 25 tahun. Dalam Psikologi Pendidikan (1993: 39) dijelaskan bahwa massa ini merupakan masa remaja akhir sampai dewasa awal, biasanya pada 
massa ini seseorang telah meninggalkan dunia anak-anak tetapi belum memiliki kedudukan dalam masyarakat. Pada akhir massa remaja, perkembangan berangsur-angsur menjadi sempurna hingga mendekati kepada kedewasaan. Ciri-ciri remaja akhir menurut Soesilowindradini (2000: 154) antara lain: kestabilan emosi meningkat, lebih matang menghadapi masalah, pikiran realistis, banyak perhatian terhadap hal baru, dan lebih mandiri. Sehingga dapat dikatakan bahwa mahasiswa prodi Ikora masih berada pada masa remaja akhir, karena sebagian besar masih berumur antara 18 sampai 20 tahun.

\section{METODE PENELITIAN}

Penelitian ini merupakan penelitian observasional dengan menggunakan angket sebagai alat untuk mengumpulkan data. Tujuan penelitian ini untuk mengetahui pemanfaatan waktu luang mahasiswa Program Studi Ilmu Keolahragaan Fakultas Ilmu Keolahragaan Universitas Negeri Yogyakarta.

Variabel dalam penelitian ini ialah pemanfaatan waktu luang, artinya. waktu dalam bentuk True Leisure, yaitu waktu luang yang dapat digunakan sebebas-bebasnya, bukan waktu luang karena terpaksa (Enforced Leisure), seperti sakit, purna tugas. Pemanfaatan waktu luang adalah kegiatan yang dilakukan di luar jam perkuliahan, dan di luar jam memelihara diri, seperti: makan, istirahat (tidur), beribadah dan perawatan badan. Kegiatan tersebut diukur menggunakan angket dengan indikator tiga faktor, yaitu: olahraga dan permainan (games and sports), kegiatan kesenian (arts and crafts), dan aktivitas alamiah (nature activity).

Dalam penelitian ini yang menjadi populasi penelitian adalah mahasiswa Program Studi Ilmu Keolahragaan Fakultas Ilmu Keolahragaan Universitas Negeri Yogyakarta angkatan 2004, 2005, 2006, dan 2007 yang masih terdaftar sebagai mahasiswa pada prodi Ilmu Keolahragaan dan belum mengajukan Tugas Akhir Semester. Jumlah populasi sebanyak 103 mahasiswa, dan jumlah setiap angkatan dapat dilihat pada tabel 1 berikut ini.

Tabel 1. Data Populasi Penelitian

\begin{tabular}{|c|c|c|c|c|c|}
\hline Angkatan & 2004 & 2005 & 2006 & 2007 & Jumlah Total \\
\hline Jumlah & 9 & 31 & 28 & 35 & 103 \\
\hline
\end{tabular}

Untuk menentukan jumlah sampel dengan menggunakan Nomogram Harry King. Sampel yang digunakan dalam penelitian ini sebanyak 60 orang mahasiswa, dan teknik pengambilannya dengan simple random sampling. Instrumen yang digunakan berupa angket (kuesioner). Validitas instrumen dicari dengan korelasi bagian dan keseluruhan (part with wole metod), menggunakan rumus korelasi Product Moment, sedangkan untuk mencari reliabilitas instrumen dalam penelitian ini menggunakan rumus Alpha Cronbach. 
Teknik Pengumpulan Data dengan menggunakan angket tertutup, yaitu angket yang sudah tersedia jawaban, sehingga responden tinggal memilih salah satu jawaban dengan memberi tanda pada kolom yang sesuai. Skor pada masing-masing alternatif jawaban adalah sebagai berikut; Selalu $=4$, Sering $=3$, Jarang $=2$, dan Tidak Pernah $=1$. Untuk butir negatif $;$ Selalu $=1$, Sering $=2$, Jarang $=3$, dan Tidak Pernah $=4$.

Teknik analisis data penelitian ini dengan analisis statistik deskriptif kuantitatif yang diterangkan dalam bentuk persentase. Setelah diperoleh persentasenya, kemudian dikelompokkan ke dalam lima kategori, pengelompokan tersebut berdasarkan pada hasil perhitungan mean dan standar deviasi, seperti pada tabel 2 berikut ini.

\section{Tabel 2. Kriteria Penilaian}

\begin{tabular}{|c|c|c|}
\hline No & Interval & Kriteria \\
\hline 1 & $\mathrm{Mi}+1,5 \mathrm{SDi}<\mathrm{x}$ & SANGAT BAIK \\
\hline 2 & $\mathrm{Mi}+0,5 \mathrm{SDi}<\mathrm{x} \leq \mathrm{Mi}+1,5 \mathrm{SDi}$ & BAIK \\
\hline 3 & $\mathrm{Mi}-0,5 \mathrm{SDi}<\mathrm{x} \leq \mathrm{Mi}+0,5 \mathrm{SDi}$ & CUKUP \\
\hline 4 & $\mathrm{Mi}-1,5 \mathrm{SDi}<\mathrm{x} \leq \mathrm{Mi}-0,5 \mathrm{SDi}$ & KURANG \\
\hline 5 & $\mathrm{x} \leq \mathrm{Mi}-1,5 \mathrm{SDi}$ & SANGAT KURANG \\
\hline
\end{tabular}

\section{HASIL PENELITIAN}

Deskripsi hasil penelitian terlebih dahulu mencari Mean dan Standar Deviasi. Mean variabel ini sebesar 77,5, dan standar deviasinya 15,5, sehingga hasil pengkategorian dapat dilihat pada tabel 3 berikut ini.

Tabel 3. Hasil Penelitian Pemanfaatan Waktu Luang

\begin{tabular}{|c|c|c|c|c|}
\hline No & Interval & Frekuensi & Persentase & Kategori \\
\hline 1 & $100,75<x$ & 1 & $1,7 \%$ & Sangat Baik \\
\hline 2 & $85,25<x \leq 100,75$ & 6 & $10 \%$ & Baik \\
\hline 3 & $69,75<x \leq 85,25$ & 26 & $43,3 \%$ & Cukup \\
\hline 4 & $54,25<x \leq 69,75$ & 23 & $38,3 \%$ & Kurang \\
\hline 5 & $x \leq 54,25$ & 4 & $6,7 \%$ & Sangat Kurang \\
\hline & Jumlah & 60 & $100 \%$ & \\
\hline
\end{tabular}

Berdasarkan tabel 3, pemanfaatan waktu luang mahasiswa program studi Ilmu Keolahragaan dapat dibedakan menjadi 5 kategori, yaitu: kategori sangat baik ada 1 orang dengan persentase sebesar $1,7 \%$, kategori baik ada 6 orang dengan persentase 
sebesar $10 \%$, kategori cukup ada 26 orang dengan persentase sebesar 43,3\%, kategori kurang ada 23 orang dengan persentase sebesar 38,3\%, dan sangat kurang ada 4 orang dengan persentase sebesar $6,7 \%$. Dari perhitungan hasil rerata, pemanfaatan waktu luang mahasiswa program studi Ilmu Keolahragaan FIK UNY dalam kategori cukup.

Hasil penelitian juga mendeskripsikan ketiga faktornya. Faktor tersebut adalah olahraga dan permainan (games and sport), kesenian (arts and craft), dan aktivitas alamiah (nature activity). Pertama, faktor olahraga dan permainan. Besarnya mean faktor olahraga dan permainan adalah 37,5 , dan standar deviasinya 7,5, sehingga hasil pengkategorian dapat dilihat pada tabel 4 berikut ini.

Tabel 4. Distribusi Frekuensi Faktor Olahraga dan Permainan

\begin{tabular}{|c|c|c|c|c|}
\hline No & Interval & Frekuensi & Persentase & Kategori \\
\hline 1 & $48,75<x$ & 6 & $10 \%$ & Sangat Baik \\
\hline 2 & $41,25<x \leq 48,75$ & 6 & $10 \%$ & Baik \\
\hline 3 & $33,75<x \leq 41,25$ & 28 & $46,7 \%$ & Cukup \\
\hline 4 & $26,25<x \leq 33,75$ & 12 & $20 \%$ & Kurang \\
\hline 5 & $x \leq 26,25$ & 8 & $13,3 \%$ & Sangat Kurang \\
\hline & Jumlah & 60 & $100 \%$ & \\
\hline
\end{tabular}

Berdasarkan tabel 4, pemanfaatan waktu luang untuk olahraga dan permainan dapat dibedakan menjadi 5 kategori, yaitu: kategori sangat baik ada 6 orang dengan persentase sebesar $10 \%$, baik ada 6 orang dengan persentase sebesar $10 \%$, cukup ada 28 orang dengan persentase sebesar $46,7 \%$, kurang ada 12 orang dengan persentase sebesar $20 \%$, dan sangat kurang ada 8 orang dengan persentase sebesar 13,3\%. Dari perhitungan hasil rerata, faktor olahraga dan permainan dalam kategori cukup.

Kedua, faktor kesenian. Besarnya mean faktor kesenian adalah 20 dan standar deviasinya 4, sehingga hasil pengkategorian dapat dilihat pada tabel berikut 5 ini.

Tabel 5. Distribusi Frekuensi Faktor Kesenian

\begin{tabular}{|c|c|c|c|c|}
\hline No & Interval & Frekuensi & Persentase & Kategori \\
\hline 1 & $26<x$ & 0 & $0 \%$ & Sangat Baik \\
\hline 2 & $22<x \leq 26$ & 4 & $6,6 \%$ & Baik \\
\hline 3 & $18<x \leq 22$ & 18 & $30 \%$ & Cukup \\
\hline 4 & $14<x \leq 18$ & 10 & $16,7 \%$ & Kurang \\
\hline 5 & $x \leq 14$ & 28 & $46,7 \%$ & Sangat Kurang \\
\hline \multicolumn{2}{|r|}{ Jumlah } & 60 & $100 \%$ & \\
\hline
\end{tabular}


Berdasarkan tabel 5, pemanfaatan waktu luang dengan melakukan kesenian dapat dibedakan menjadi 5 kategori: kategori sangat baik tidak ada, persentase sebesar $0 \%$, baik ada 4 orang dengan persentase sebesar 6,6\%, cukup ada 18 orang dengan persentase sebesar $30 \%$, kurang ada 10 orang dengan persentase sebesar $16,7 \%$, dan sangat kurang ada 28 orang dengan persentase sebesar $46,7 \%$. Dari perhitungan hasil rerata, faktor kesenian dalam kategori kurang.

Ketiga, faktor aktivitas alamiah. Mean faktor ini adalah 20 dan standar deviasinya 4, sehingga hasil pengkategorian dapat dilihat pada tabel 6 berikut ini.

Tabel 6. Distribusi Frekuensi Faktor Aktivitas Alamiah

\begin{tabular}{|c|c|c|c|c|}
\hline No & Interval & Frekuensi & Persentase & Kategori \\
\hline 1 & $26<x$ & 0 & $0 \%$ & Sangat Baik \\
\hline 2 & $22<x \leq 26$ & 5 & $8,3 \%$ & Baik \\
\hline 3 & $18<x \leq 22$ & 25 & $41,7 \%$ & Cukup \\
\hline 4 & $14<x \leq 18$ & 20 & $33,3 \%$ & Kurang \\
\hline 5 & $x \leq 14$ & 10 & $16,7 \%$ & Sangat Kurang \\
\hline \multicolumn{2}{|r|}{ Jumlah } & 60 & $100 \%$ & \\
\hline
\end{tabular}

Berdasarkan table 6, faktor Aktivitas Alamiah dapat dibedakan menjadi 5 kategori: kategori sangat baik tidak ada, persentase sebesar $0 \%$, baik ada 5 orang dengan persentase sebesar 8,3\%, cukup ada 25 orang dengan persentase sebesar $41,7 \%$, kurang ada 20 orang dengan persentase sebesar $33,3 \%$, dan sangat kurang ada 10 orang dengan persentase sebesar $16,7 \%$. Dari perhitungan hasil rerata, faktor aktivitas alamiah dalam kategori cukup.

\section{KESIMPULAN}

Berdasarkan hasil penelitian dan pembahasan pemanfaatan waktu luang mahasiswa Program Studi Ilmu Keolahragaan FIK UNY, dari 60 mahasiswa dibedakan menjadi 5 kategori, yaitu: kategori sangat baik ada 1 orang dengan persentase sebesar 1,7\%, kategori baik ada 6 orang dengan persentase sebesar $10 \%$, kategori cukup ada 26 orang dengan persentase sebesar $43,3 \%$, kategori kurang ada 23 orang dengan persentase sebesar 38,3 $\%$, dan sangat kurang ada 4 orang dengan persentase sebesar $6,7 \%$. Dari perhitungan rerata dapat disimpulkan bahwa pemanfaatan waktu luang mahasiswa Program Studi Ilmu Keolahragaan FIK UNY dalam kategori cukup. Faktor olahraga dan permainan dalam kategori cukup, faktor aktivitas alamiah dalam kategori cukup, dan faktor kesenian dalam kategori kurang. 


\section{DAFTAR PUSTAKA}

Jensen, Clayne R. (1997). Outdoor Recreation in America (Trends, Problems, and Opportunities). Minneapolis, Minnesota: Burgess Publishing Company.

Butler, George D. (1976). Introduction to Community Recreation. USA: McGraw-Hill Book Company.

Hartoto, J. (1983). "Peranan Rekreasi bagi Kehidupan Keluarga". Majalab. Yogyakarta: PPM IKIP Yogyakarta.

(1990). "Pentingnya Pendidikan Rekreasi di Sekolab". Majalab. Yogyakarta: PPM IKIP Yogyakarta. Muhammad Murni dan Yudha M. Saputra. (2000). Pendidikan Rekreasi. Depdikbud.

Haag, Herbert. (1994). Theoretical Foundation of Sport Science as A Scientific Discipline (Contribution to A Pbilosopby Meta-Theory) of Sport Science. Federal Republic of Germany: Verlag Karl Hoffmann GmbH \& Co.

Russell, Ruth V. (1982). Planning Programs in Recreation. Missouri: The C. V. Mosby Company. http://popsy.wordpress.com/2007/06/05/mengisi-celah-waktu-luang / 4.15

http://www.pintunet.com/cetak.php?xpid=bkagmis mitpus ahm1\&un=Boim\&ref=2004/ $\underline{03 / 05032004 / 22428}$ 